\title{
REVITALISASI KEPEMIMPINAN UNTUK MENINGKATKAN MUTU PENDIDIKAN MADRASAH
}

\author{
Husnan Abrori \\ Universitas Nurul Jadid \\ Email: husnan.abrori@gmail.com
}

\begin{abstract}
There are no stupid people; there are people who do not know or are late to know. It is best for leaders to humanize humans, provide motivation, give opportunities for creativity to emerge, cultivate them according to their capacity so that innovation and their imagination do not sleep. A good leader will not look for mistakes blindly, or blame in public. Angry in public is killing human characters. The implication is that they will be quiet and lazy to innovate because there is no appreciation. So that they just become obedient and say it's up to the leader. Leaders who are imprisoned in respect and appreciation only will feel happy to be respected and respected even though it is another name for the sleeping of subordinate creativity. The worse is the top down instruction model leader who is an admirer of the institutional hierarchy who places a leader as the highest authority in the management area, so he always feels right, and taboo to be criticized and blamed. Apologies, ask for help, thank you for never coming out in verbal linguistics. There are only procedures, concepts, rigid instructions that are haram to be criticized. Therefore it is necessary to revitalize leadership in the madrasa.
\end{abstract}

Keywords. Revitalization of Leadership, Quality of Education, Madrasas.

Abstrak. Sesungguhnya tidak ada manusia bodoh, yang ada belum tahu, atau terlambat tahu, sebaik-baiknya pemimpin memanusiakan manusia, memberi motivasi, memberi kesempatan agar kreatifitas muncul, mengorangkan mereka sesuai kapasitasnya sehingga inovasi dan imajinasi mereka tidak tidur. Pemimpin yang baik tidak akan mencari kesalahan dengan membabi buta, atau menyalahkan didepan umum, marah di depan umum itu adalah pembunuhan karakter manusia, implikasinya adalah mereka akan diam dan males untuk kembali berinovasi dalam wadah kreatifitas karena tidak ada apresiasi (penghargaaan) sehingga hanya menjadi penurut dan mengatakan terserah pimpinan gimana enaknya saya menurut saja, pemimpin yang terpenjara dalam penghormatan dan penghargaan akan merasa dihargai dan dihormati senangya bukan main padahal itu adalah nama lain dari tidurnya kreatifitas bawahan, yang lebih parah lagi pemimpin model top down instruction yang merupakan pengagum institusi hierarki menempatkan seorang leader sebagai pemegang kekuasaan tertinggi di areal manajemen merasa paling benar dan tabu untuk dikritik dan disalahkan. Ucapan minta maaf, minta tolong, terima kasih tidak pernah keluar dalam verbal linguistiknya yang ada hanya prosedur, konsep, intruksi kaku yang haram untuk dikritik. Oleh karenanya perlu revitalisasi kepemimpinan di madrasah.

Kata kunci. Revitalisasi Kepemimpinan, Mutu Pendidikan, Madrasah.

Copyright (C JMPI: Jurnal Manajemen Pendidikan Islam. All Right Reserved.

This is an open access article under the CC BY-NC-ND license

(http://creativecommons.org/licenses/by-nc-nd/4.0/). 


\section{A. PENDAHULUAN}

Edwaard sallis (2012) dalam bukunya Total Quality Management In Education mengatakan dalam konsep manajemen mutu pendidikan perlu adanya institusi terbalik dengan menempatkan customer di posisi teratas dalam areal management, baik customer internal maupuan eksternal, lalu guru di nomer dua, setelah itu dipaling bawah adalah leader sebagai pendengar yang baik lalu respon, dan melayani dengan baik. Bukan berarti pada tataran instruksional menjadi terbalik akan tetapi bagaimana seorang pemimpi mampu mengakomodasi keinginan-keinginan dengan baik dan berusaha mengaktualisasikan secara berkelanjutan (Server Leadership).

Dr. Joseph Wong (2011) dalam buku I Ching Management mengatakan sekawanan naga tanpa pemimpin, karena semua adalah naga dengan kemampuannya masing-masing, artinya pemimpin tidak merasa dirinya sebagai pemimpin, semuanya adalah pemimpin dalam tugasnya masing-masing, bekerja sesuai tupoksinya. Dengan kata lain kepemimpinan kelompok, dimana setiap orang dapat mngembangkan kekuatannya dan berinteraksi satu sama lain untuk bersamasama mengembangkan organisasi. Pemimpin seharusnya mampu bekerja sama dengan baik melebur menjadi satu tubuh dalam team dengan tidak merasa bahwa dirinya adalah atasan melainkan rekan kerja dengan job description berbeda. Dengan adanya kepemiminan yang baik diharapkan mutu pendidikan madrasah menjadi meningkat sehingga menarik market untuk memakai jasanya sebagai pengantar masa depan generasi bangsa dan pengawal peradaban menuju hari esok yang lebih baik. Sistem penjaminan mutu pendidikan tergantung pada orang yang mengelola manajemen pendidikan tersebut yaitu kepala madrasah dan dewan asatid.

Hasan Baharun dan Zamroni (2017) dalam buku manajemen pendidikan mengatakan Mutu Input dapat dilihat dari beberapa aspek diantaranya situasi dan kondisi baik tidaknya input sumberdaya manusia, seperti pimpinan dan dewan asatidz. Artinya kualitas human resource ditentukan oleh keberadaan seorang pemimpin yang keberadaannya mampu menjadi solusi konstruktif dalam segala dimensi problematic kehidupan dalam lingkaran dunia kependidikan dan tampil terdepan bersama pasukan akademiknya yaitu guru untuk mengawal proses sehingga menghasilkan output yang berkualitas, maka disinilah perlu high performance dari semua areal management pendidikan untuk mengaktualisasikan diri dalam sebuah kinerja yang transformatif.

Ahmad syahidah (2018) juga mengatakan pemimpin yang baik pernah menjadi bawahan yang baik. Filosofi ini menggambarkan bahwa pengalaman seseorang akan mengantarkan kedewasaan dalam segala pemikiran, pergerakan dan keputusan. Sejalan dengan hal tersebut basic seorang pemimpin yang baik yang berasal dari seorang bawahan yang berdedikasi tinggi ketika menjadi pemimpin akan menjadi pemimpin yang ngemong kepada bawahannya karena dalam proses perjalanan kariernya pernah menjadi bawahan.

Ahmad Fauzi (2015) dalam bukunya berjudul Kepemimpinan Spiritual mengatakan 30\% brain trust spiritual leader, menghabiskan 30\% waktunya untuk berpikir, mempercayai dan mengembangkan, pengambilan keputusan berdasarkan logika berpikir. Penyatuan antara kecerdasan emosional question, spiritual question menjadi hal yang urgen dalam membentuk kapabelity dari seorang leader, maka perlu keseimbangan antara kedua hal tersebut yang nantinya akan teraktualisasi pada 
pemikiran sehingga ide dan gagasan yang muncul akan murni dan diterima oleh akal, hati semua pihak karena berasal dari pemikiran dan perenungan yang mendalam. Dalam perjalanannya memang banyak problem di madrasah yang perlu pemikiran dan penyelesaian oleh karenanya dalam mencari problem solving perlu menuntaskan ke akar-akarnya.

Akmal Mundiri mengatakan memandanglah ke hulu (memandang ke akar masalah, bukan pada masalahnya). Justifikasi kesalahan terhadap sebuah masalah menjadi hal yang patut dihidari karena semuanya harus diurai pada akar persoalan, ibarat penyakit diberi obat tuntas sampai ke akar penyebab dari penyakit tersebut sehingga kemungkinan untuk kambuh tidak akan terjadi. Dalam konteks ini bisa digunakan analisis fish bone tulang ikan ataupun akar pohon persoalan untuk menemukan hulu atau ujung dari sebuah persoalan. Dan yang lebih penting dari itu semua adalah keteladanan, kesempatan dan dukungan dari seorang pemimpin pada bawahannya.

Kihajar Dewantara mengatakan Ing ngarso sung tulodo (di depan memberi contoh dan tauladan), Ing madya mangun karso(di tengah memberi kesempatan untuk mengembangkan diri), Tut wuri handayani (di belakang mendorong). Pendidikan merupakan penjual jasa maka tidak boleh ada kegagalan dalam pelayanan, harus baik dari awal dan seterusnya. Oleh karenanya kehadiran pemimpin yang menginspirasi dengan roh tranformalitas dan akuntabilitas sangat urgen, bergerak sebagai bagian dari team (Superteam) bukan menonjolkan diri (Superman), artinya menjadi orang bermanfaat tapi bukan menonjolkan diri, menjadi pemimpin yang dicintai ketika ada, dirindukan ketika tiada. Bukan sebaliknya ditakuti ketika ada dan senang ketika tiada.

Fenomena kepemimpinan di madrasah di era sekarang adalah adanya kepemimpinan yang meletakkan tugas pokok dan fungsinya pada pundak operator, sehingga terkadang kepala madrasah tidak tahu tentang beberapa hal akan tetapi yang lebih menguasai adalah operatornya. Keberadaan pemimpin di sebagian madrasah hanya sebatas pengawasan kegiatan belajar mengajar, sebatas mencari kesalahan, mencari celah dari bawahannnya, yang ada hanya marah, anti kritik. Nah ini yang menjadi pemikiran penulis sehingga perlu untuk mengingatkan kembali dalam seutas kertas pena dalam bentuk tulisan sebagai tanda cinta penulis pada madrasah. Melalui tulisan ini penulis ingin mengarahkan kembali (Reorientasi) kepemimpinan di madrasah pada tugas pokok dan fungsinya untuk membentuk mutu madrasah lebih baik lagi sehingga lebih marketable.

\section{B. PEMBAHASAN}

Pemimpin merupakan nakhoda yang mampu mengantarkan kapal dan penumpang sampai pada tujuannya dengan selamat dan penuh kebahagiaan walau dalam perjalanan ada badai dan gelombang menghadang akan tetapi seorang pemimpin dengan high performance akan tampil sebagai motivator tim sehingga tetap kompak memandang ke depan tentang tujuan yang akan dicapai. Kepemimpinan, sampai hari ini dianggap sebagai faktor yang sangat penting dalam sebuah organisasi. Leadership is a relational process and involves connections with individuals (Summer F. Odom, 2013). Kepemimpinan dalam hal ini dimaknai sebagai proses mempengaruhi orang lain dalam suatu komunitas yang diarahkan untuk 
tercapainya tujuan bersama. Pemimpin sebagai komunikator merupakan pihak yang menentukan, apa, bagaimana, bila mana, dan di mana perintah itu dikerjakan agar keputusan dapat dilaksanakan secara efektif. Kepemimpinan yang efektif membutuhkan kompetensi atau kemampuan untuk menggerakkan dan memotivasi orang lain agar mau melaksanakan sesuatu yang diinginkan oleh pemimpin (Veithzal Rivai and Deddy Mulyadi, 2012).

Kepemimpinan dalam organisasi memiliki peran yang sangat besar dalam membangun hubungan antar individu dan pembentuk nilai organisasi yang dijadikan sebagai pondasi dasar bagi pencapaian tujuan organisasi. Pengaruh kepemimpinan terhadap efektivitas organisasi dapat dilihat sebagai efek kepemimpinan langsung dan tidak langsung (Herminingsih, 2011). Mengingat pentingnya pemimpin, dapat diketahui bahwa fungsi utama pimpinan pada satuan pendidikan, seperti kepala madrasah adalah menciptakan situasi belajar mengajar sehingga guru-guru dapat mengajar dan murid-murid dapat belajar dengan baik. Dalam melaksanakan fungsi tersebut, kepala madrasah memiliki tanggung jawab ganda yaitu melaksanakan administrasi madrasah sehingga tercipta situasi belajar mengajar yang baik dan melaksanakan supervisi sehingga kompetensi guru bertambah dan menjadi professional (Baharun, 2017).

Tugas seorang pemimpin antara lain adalah mempengaruhi orang yang dipimpin untuk bersikap dan berperilaku sesuai dengan visi, misi, core values dan core belief organisasi. Pemimpin spiritual adalah pemimpin yang mempengaruhi orang yang dipimpin dengan cara mengilhamkan, mencerahkan, menyadarkan, membangkitkan, memampukan, dan memberdayakan lewat pendekatan spiritualitas atau nilai-nilai etis religius. Nilai- nilai etis religius inilah yang berperan sebagai mission-focused, vision-directed, philosophy driven dan value-based institution (Fauzi, 2015).

Pada tataran teoritis, kepemimpinan dalam Islam harus mampu memberikan perubahan dan pembaharuan secara signifikan sehingga melahirkan kepemimpinan yang kuat (strong leadership) dan harus memiliki konsepsi yang berbeda dengan teori kepemimpinan pada umumnya. Konsepsi kepemimpinan pendidikan yang kuat adalah kepemimpinan yang visioner dan mampu membangun budaya orgasisasi yang efektif dan iklim organisasi yang kondusif. Kepemimpinan pendidikan Islam yang efektif dengan akan melahirkan lembaga pendidikan yang efektif dan membanggakan. Hasil penelitian Edmonds (1979) mengemukakan bahwa, lembaga pendidikan yang dinamis senantiasa berupaya untuk meningkatkan prestasi kerjanya yang baik dengan beberapa komponen dalam kelembagaan pendidikan tersebut.

Pada konteks tersebut pendidikan menjadi yang tempat strategis dan untuk mengantarkan cita-cita ideal dimaksud, maka dibutuhkan sistem manajemken strategis dalam pengelolaan pendidikan. Pada aspek yang lain optimalisasi manajemen dalam pendidikan adalah sesuatu yang penting, karena pendidikan sebagai lembaga noble industry mengemban misi ganda antara profit dan sosial, misi sosial dapat dicapai secara maksimal apabila lembaga atau organisasi tersebut memiliki capital human capital dan sosial capital yang memadai dan efektifitas yang tinggi (Tobroni, 2002). Karena itu menjadi manager pendidikan tidak hanya dengan pengetahuan dan profesionalisme akademik saja, tetapi juga dengan 
misi "niat" suci, inilah yang dimaksud oleh penulis sebagai makna dan eksistensi dari kegiatan manajemen pendidikan Islam, karena itu manajemen pendidikan Islam merupakan sesuatu yang absah untuk kita urai dalam tulisan ini (Baharun, 2017).

Sebagai pemimpin pendidikan, Kepala madrasah memegang peranan yang penting dalam meletakkan pondasi pendidikan bagi pengelolaan dan pengembangan sumber daya manusia di lembaganya. Oleh karena itu, kepala madrasah harus membekali dirinya dengan jiwa kepemimpinan, inovasi, kompetensi, skill dan kreativitas yang tinggi agar lembaganya dapat berkembang dengan pesat (Niniek Widiarochmawati, 2010). Hal ini sesuai dengan Kepmendiknas Nomor 13 Tahun 2007 tentang Standar kompetensi yang harus dimiliki oleh Kepala Sekolah/Kepala Madrasah, yaitu; kompetensi kepribadian, kompetensi manajerial, kompetensi kewirausahaan, kompetensi supervisi dan kompetensi sosial (Tarsono, 2012).

\section{KESIMPULAN}

Keberadaan pemimpin di madrasah sangat menentukan ketercapain standar mutu yang telah ditetapkan di awal bersama tim. Sesungguhnya di madrasah terdapat sumber daya manusia kompeten walau dalam keterbatasan sumber daya keuangan dan sumber daya sarana. Keterbatasan tersebut bukan halangan untuk menembus batas dan terbang lebih tinggi bersama tim. Selain memiliki kompetensi untuk menguatkan tugas pokok dan fungsi kepemimpinan, madrasah memerlukan adanya pemimpin yang mampu menjadi educator, motivator, actor, inspirator bagi bawahannya. Dengan demikian maka gelora perubahan selalu berkobar di dada para punggawanya yang tak akan berhenti sampai tujuan tercapai karena selalu ada bahan bakar motivasi dari sang nakhoda untuk selalu melihat, bergerak, menyelesaikan persoalan tanpa diperintah tapi punya inisiatif sendiri untuk bergerak tanpa lelah karena mereka merasa dengan kekompakan semua lini maka sebentar lagi sampai pada finish tujuan,dan memang harus ada finish dari sebuah visi, jika ada keberlanjutan perbaikan itu sah saja setelah pada tahapan evaluasi standar yang kita kenal dengan continous improvement.

\section{REFERENSI}

Fauzi, Ahmad. (2015). Membangun Epistemologi Pendidikan Islam Melalui Kepemimpinan Spiritual : Suatu Telaah Diskursif . Empirisma Vol 24.

Edmonds. R. (1979)“Some School Work and More Can”, dalam Social Policy No. 9, Muhaimin, Suti'ah \& Sugeng Listyo Prabowo. (2009). Manajemen Pendidikan. Jakarta. Kencana Prenada Media Group.

Syafe'I, Imam. dkk. (2012). Pendidikan Agama Islam Berbasis Karakter Di Perguruan Tinggi. Jakarta. PT Raja Grafindo Persada

Tim PGRI. (2014). Pendidikan Untuk Transformasi Bangsa. Jakarta. PT Kompas Media Nusantara

Lukito, Penny Kusmatuti. (2014). Membumikan Transparansi dan Akuntabilitas Kinerja

Sektor Publik: Tantangan Berdemokrasi Ke Depan. Jakarta. PT.Gramedia Widiasarana Indonesia.

Sallis, Edward. (2012). Total Quality Management In Education. Jogjakarta. IrGiSod,. 
Wong, Joseph. (2011). I Ching Management : Menguasai Kearifan Bisnis China. Jakarta: PT. Gramedia.

Baharun, Hasan \& Zamroni. (2017). Manajemen Mutu Pendidikan. Tulung Agung: Akademia Pustaka.

Syahidah, Ahmad. (2018). Forum Ilmiah Filsafat Management Pendidikan. Paiton: UNUJA.

Fauzi, Ahmad. (2015). Membangun Epistemologi Pendidikan Islam Melalui Kepemimpinan Spiritual: Suatu Telaah Diskursif (Empirisma Vol 24 No. 2 Juli 2015)

F. Odom, Summer. (2013). "Social Media Tools in the Leadership Classroom: Students' Perceptions of Use Journal of Leadership Education," Journal of Leadership Education 12, no. 1

Deddy Mulyadi, and Veithzal Rivai. (2012). Kepemimpinan dan Prilaku Organisasi. Jakarta: PT. Raja Grafindo Persada.

Herminingsih, Anik. (2011). “Pengaruh Kepemimpinan Transformasional Terhadap Budaya Organisasi". Jurnal Ilmiah Ekonomi Manajemen dan Kewirausahaan "Optimal” Vol.5, No.1.

http://ejournalunisma.net/ojs/index.php/optimal/article/view/443/417

Baharun, Hasan. (2017). "Peningkatan Kompetensi Guru". Jurnal Ilmu Tarbiyah Jurnal Ilmu Tarbiyah. “ At -Taj Did ”. Vol. 6, No .1, Januari 2017', 1-25

Tobroni. (2012). The Spiritual Leadership: Mengefektifkan Organisasi Noble Industry Melalui Prinsip-Prinsip Spiritual Etis. Malang: UMM

Widiarochmawati, Niniek. (2010). "Kepemimpinan Kharismatik Wanita Kepala Sekolah Dasar Di Kabupaten Tuban," Jurnal Prospektus VII, no. 1

Tarsono, Tarsono. (2012). "Pengaruh Kompetensi Manajerial, Supervisi dan Kewirausahaan Terhadap Kinerja Kepala MI Negeri Se Kabupaten Brebes," Journal of Economic Education. 